\title{
An Experimental Work on the Performance of Single Solar Still with Parabolic Trough Collector in Hot Climate Conditions
}

\author{
Hawraa Fadhel $^{1 *}$, Qahtan A. Abed ${ }^{2}$, Dhafer M. Hachim ${ }^{1}$ \\ ${ }^{1}$ Department of Technical Power Mechanics, Technical Engineering College / Najaf, Al-Furat Al-Awsat Technical University \\ (ATU), Najaf 54001, Iraq \\ ${ }^{2}$ Technical Institute / Al-Rumaitha, Al-Furat Al-Awsat Technical University (ATU), Najaf 66002, Iraq
}

Corresponding Author Email: hawraa.fadhel@student.atu.edu.iq

https://doi.org/10.18280/ijht.390526

Received: 27 August 2021

Accepted: 25 October 2021

\section{Keywords:}

solar distillation, productivity, parabolic trough collector, single slope solar still

\begin{abstract}
This study investigated the production of single slope solar still and the influence of combining with a parabolic trough collector. The effect of the different working fluid types on freshwater productivity, outlet working fluid temperature, heat gain, and thermal efficiency has been studied under the weather conditions of south city of Iraq/ Najaf $\left(32^{\circ}\right.$ $\left.1^{\prime} \mathrm{N} / 44^{\circ} 1^{\prime} \mathrm{E}\right)$. The first type was water and the second type is nanofluid. The results of the comparison showed when using water as a working fluid flowing inside the receiving tube for different days; the highest temperatures were obtained at 12:00 pm, and the average productivity of distilled water was obtained in May and June 2021 were 4.5358 and $6.733 \mathrm{~kg} / \mathrm{m}^{2} /$ day respectively. While when using the nanofluid as a working fluid flowing inside the Parabolic Trough Collector (PTC) receiver tube, the outlet temperatures were rising for the same comparison days with an increase in the productivity of distilled water. Where the freshwater productivity during the day was $8.745328 \mathrm{~kg} / \mathrm{m}^{2} / \mathrm{day}$ as, and it was $9.018119 \mathrm{~kg} / \mathrm{m}^{2} /$ day during the other day. A productivity analysis was carried out for two different working fluid types (Water and nanofluid instead of water) as a fluid running inside the receiving tube of PTC. The freshwater produced from PTC (with nanofluid) was a $42.2 \%$ improvement in productivity compared with conventional PTC.
\end{abstract}

\section{INTRODUCTION}

Water is an essential component of human nutrition; the amount of pure potable water consumed each day for cooking and other family activities are between 20 and 50 Liters of clean potable water. The drinking water (freshwater) is a significant concern in many parts of the world, regardless of whether they are developed or developing countries, due to a lack of clean water. Imposing wastewater treatment methods from various sources to make it potable can help to solve the problem of pure water supply to a large extent. To clean the contaminated water, a number of technologies are available. The evaporation method using a solar still is one of the oldest and easiest ways to do so. To work, this technique simply requires sunlight and a small amount of manpower. As a result, it may appeal to both developing and emerging countries [1]. Fathy et al. [2] investigated the performance of a double-slope solar still with a parabolic trough complex (PTC) connection. The oil tubes connected to the PTC convert the solar energy that has fallen on it to solar energy. The solar stator contains an annular heat exchanger with finned tubes. Freshwater yields of 8.53 and $4.03 \mathrm{~kg} / \mathrm{m}^{2} /$ day are still linked to consistent PTC in two seasons (summer and winter). Hassan et al. [3] Using a parabolic trough collector, the effect of a middle made of salt water on the work of dual-action solar energy has been studied experimentally. Steel wire mesh, transparent salt water, and sand impregnated with salt water were used in the bowl as salt water media. The introduction of wire nets and sand increased daily fresh water output by about $3.1 \%$, and by $13.7 \%$ in in winter, nearly $3.4 \%$ and $14.1 \%$ in summer. Al-Shamkhee et al. [4] The performance of pre-designed and produced water systems was investigated in an experimental study. For the first time, a wastewater desalination project was implemented at Najaf, Iraq $\left(32^{\circ} 1 ' \mathrm{~N} / 44^{\circ} 1^{\prime} \mathrm{E}\right)$. The proposed design attempts to increase distilled water output by including a parabolic solar basin. The first outcomes, the primary results show an $11 \%$ increase in system efficiency, and the results also show that orienting the PTC to the north or south is optimum for preserving system efficiency. Riffat et al. [5] The performance of a $\mathrm{V}$-shaped solar concentrator has been explored for water desalination applications. They claimed that the $\mathrm{v}$-trough solar concentrator is a superior approach for small and medium-scale water desalination, with a $38 \%$ efficiency at $100^{\circ} \mathrm{C}$ transfer fluid temperature at the concentrator output. Hassan et al. [6] The influence of brine middle and capacitor type on single slope solar energy work was studied experimentally. A typical solar stator fitted with a glass condenser and a still solar fitted with a flipper coated heat sink condenser are both tested. The use of a wire reticulum condenser, as well as a heat distributed and sand condenser, increased the freshwater output. Madiouli et al. [1] have experimentally examined the effect of combining a flat plate collector and running a standard sloped solar still. In addition to the parabolic trough complex supported by a spherical layer filled with glass, which works as a heat storage mechanism for the system. The results indicate that solar intensity combined with a parabolic trough collector can lead to excellent results.

Morad et al. [7] the heat transfer and energy balance 
equations have been used to perform a thermal analysis of a double slope solar house in order to predict its performance. The production of the solar stills during the variation in brine depth in the basin and the thickness of the cover glass was studied through cooling cover and without cover cooling, based on thermal analysis. through the comparison between the two types of solar still; passive and active solar still showed the maximum freshwater productivity $\left(7.8 \mathrm{~L} / \mathrm{m}^{2}\right.$.day and 10.06 $\mathrm{L} / \mathrm{m}^{2} /$ day) and internal efficiency $(57.1 \%$ and $80.6 \%)$, respectively. Harris Samuel et al. [8] Confirm the employ of thermal spherical salt storage on a solar system. They observed an improvement in freshwater production to $3.7 \mathrm{~kg} / \mathrm{m}^{2}$ when compared to the 2.7 and $2.2 \mathrm{~kg} / \mathrm{m}^{2}$ collected from the two types of general slope solar energy using and unused sponges. Olia et al. [9] they have discussed solar parabolic through collectors in various types, main components and main applications. Also, the implementation of Nanofluids is presented in different components of solar thermal collectors.

The main objective of the present work is divided into two distinct sections. The first one is to study the freshwater productivity from traditional single slope solar still with PTC. Another goal was to present the effect of nanofluids on the productivity (thermal efficiency) of the solar destinations system.

\section{EXPERIMENTAL SETUP AND MEASURING DEVICES}

\subsection{Solar still with parabolic trough collector}

Experiments were carried out on a solar parabolic trough collector (PTC) equipped with a single solar still. The experimental investigation took into account weather data such as air temperature, sun radiation, and wind speed. where a work is split into two halves; Part one is the use of water as a fluid running within the tubes to desalinate the water inside the solar still using PTC, and part two is the use of nanofluid as a working fluid that runs within the tubes. The PTC investigated in this study is that simulated by COMSOL Multiphysics [10]. The PTC is made of mirror to aid reflection and focus the sun's radiation onto an absorption tube situated at a focal line as shown in Figure 1. At the place where it absorbs, the receiver is an absorbent tube composed of copper. The water goes from the tank via the pump and into the copper tube, which is the receiver, where the incoming radiation is transformed into heat energy. The water comes out hot and then enters the solar still through tubes, then the cycle is repeated. Inside the solar still there is water of $1 \mathrm{~cm}$, it has a point to evaporate. Then pure water is collected as a result of water condensation. The numerical simulation was performed by Fadhel et al. [10]; they have designed the parabolic trough collector with single solar still. The authors tested different sizes of PTC integrated with single solar still. They have stated that the proper design of PTC is best suited to the optimal performance of their used dimension. The dimensionally of the suggested PTC and solar still are detailed in Table 1 (for details see ref. [10]).

A comparable steel frame with a highly reflective mirror was designed and manufactured as shown in Figure 1. The PTC was directed in the south direction in order to get the largest amount of solar intensity. The solar radiation is reflected and directed to the focal line of the receiver tube.

The second part of this experimental setup is a traditional single solar still see Figure 2. The water basin is made of cork, its surface is inclined at an angle of 30, covered with glass, and there is a heat exchanger inside. A set of thermocouples have been implemented in the experimental, the water temperatures inside and outside the solar still are measured, as well as the internal and external glass surface temperature and heat exchanger temperature.

Table 1. The dimensional of PTC and solar still

\begin{tabular}{cc}
\hline Parameter & Value \\
\hline Aperture width for parabolic trough collector & $0.8[\mathrm{~m}]$ \\
Trough length & $1.4[\mathrm{~m}]$ \\
Aperture area & $1.12\left[\mathrm{~m}^{2}\right]$ \\
Concentration ratio & $13.091[-]$ \\
Inner diameter of receiver tube & $0.016[\mathrm{~m}]$ \\
Outer diameter of receiver tube & $0.019[\mathrm{~m}]$ \\
Width of single solar still & $0.38[\mathrm{~m}]$ \\
Length of single solar still & $0.61[\mathrm{~m}]$ \\
Rim angle & $90^{\circ}$ \\
\hline
\end{tabular}

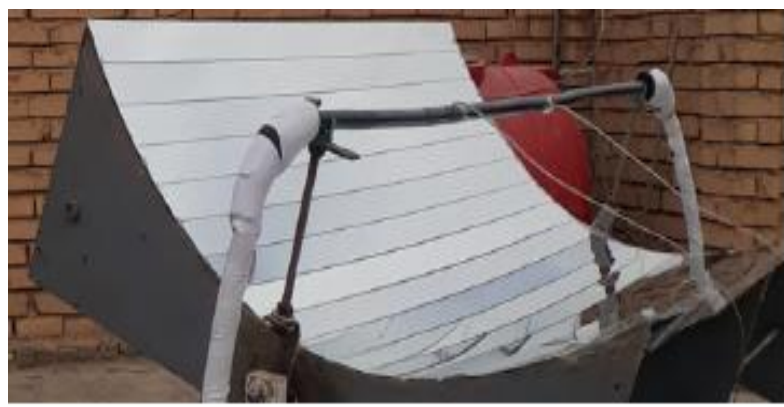

Figure 1. Photograph for the parabolic trough solar collector with the receiver tube

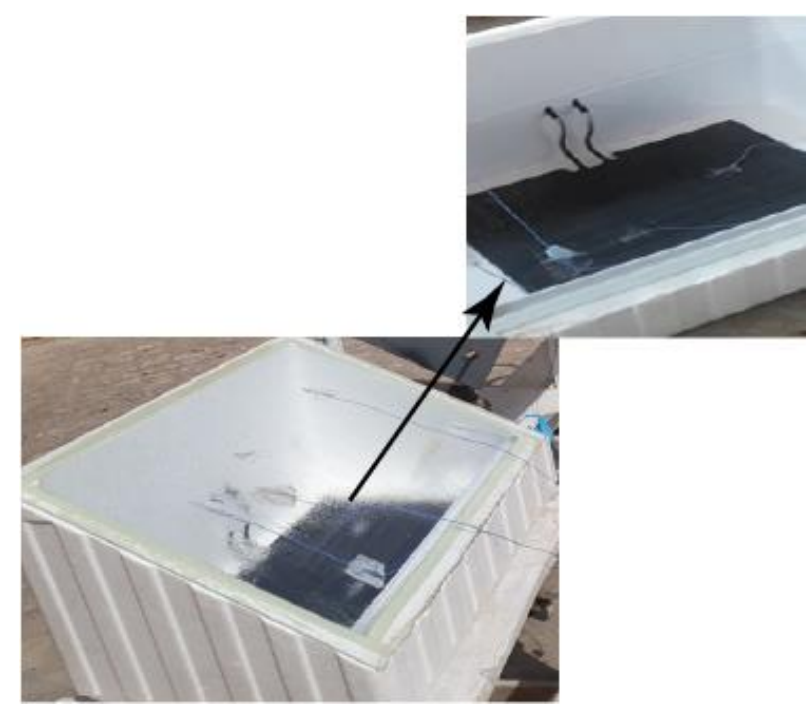

Figure 2. Single solar still with heat exchanger

The experimental devices of the presented study were setup at the roof of the Engineering Technical College Najaf building, Al-Furat Al-Awsat Technical University having Latitude $32^{\circ} 1$ ' $\mathrm{N}$, longitude $44^{\circ} 19^{\prime} \mathrm{E}$ and elevation above sea level: $41 \mathrm{~m}$ (see Figure 3). 


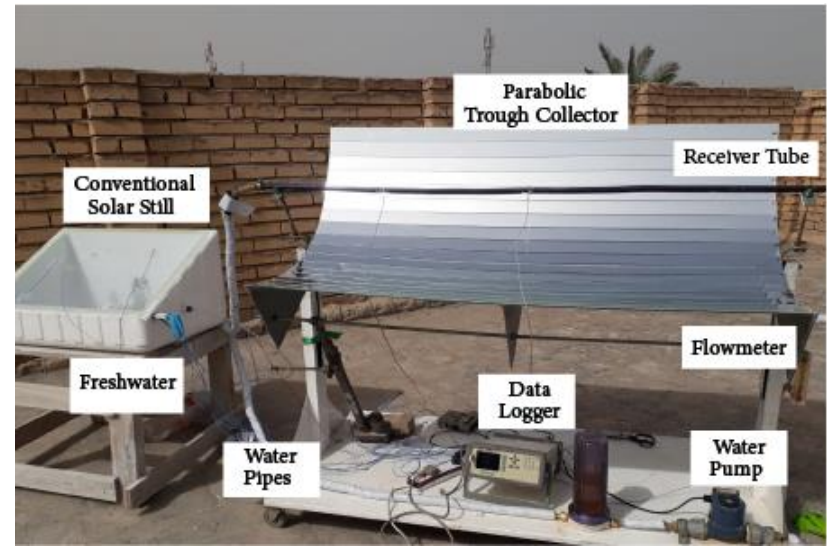

Figure 3. Photo of the experimental setup (conventional solar still with parabolic trough collector)

\subsection{Preparation of nanofluid (copper oxide)}

The largest of the usual working fluids in PTC is water. The PTC water type present great advantages as easy thermal storage, safety working and the water is non-toxic fluid. The conditions of using the water are based on the need for limitation temperatures $[11,12]$. The next section is the work that uses Nanofluids as a thermal working fluid. The development of nanofluids is an essential step to increase the thermal conductivity of the working fluids. The preparation nanofluids is the primary step of this experimental study. The previous researchers suggested many preparation methods that each of them has some advantages and disadvantages. There were three methods for this nanofluid's preparation [13]; the first one is variable the $\mathrm{PH}$ amount of the suspensions; the second method is the addition of the surfactants to the suspensions; while the last method is putting the nanofluid in an ultrasonic apparatus. In this study a nanofluid is copper oxide $(\mathrm{CuO})$ have used, from the nanoparticles were suspended with $1 \%$ pure water $(\mathrm{PH} 6.6)$ for the production of nanofluids. The preparation vessel containing pure water and nanoparticles was placed inside the ultrasonic device for 3 hours at a frequency of $37 \mathrm{~Hz}$ and a power of $100 \mathrm{~W}$ (Elma ultrasonic device), as shown in Figure 4.

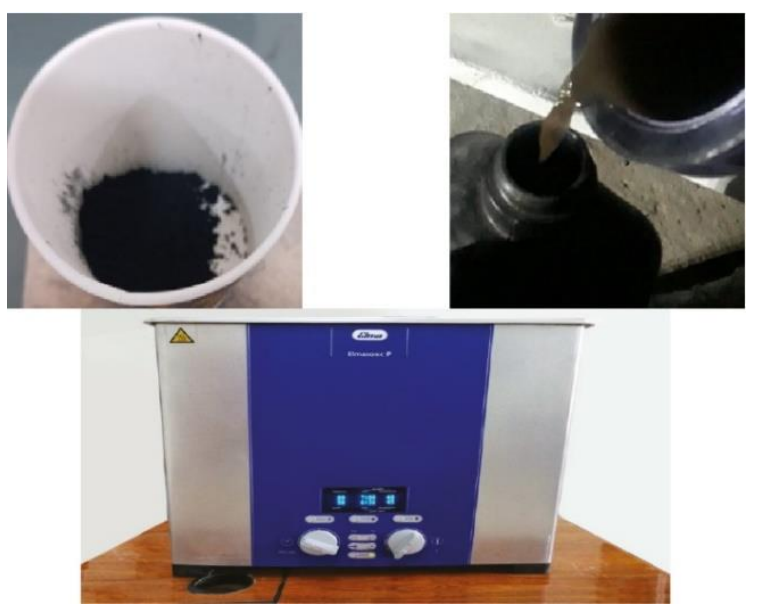

Figure 4. Preparation of nanofluid; Elma ultrasonic device and Copper Oxide $(\mathrm{CuO})$

Gum Arabic (GA) was added in a small percentage to the solution after mixing it with water to prevent clumping when added to the nano solution. Gum Arabic is a heterogeneous substance because it is a nonionic surfactant. The natural gum produced by acacia species such as acacia senegal and acacia seyal is known as GA. They dissolve quickly in water, yielding a transparent solution ranging in hue from pale yellow to orange-brown. It also has a $\mathrm{pH}$ of about 4.5 and a viscosity of extremely low $[14,15]$. The stability of nanoparticles was monitored for 15 days, and no nanoparticle deposits were found during this period. As for the particles that were exposed only to ultrasound without adding GA, they were deposited during a short period. Table 2 properties of Copper Oxide $(\mathrm{CuO})$ and amino acid composition for Gum Arabic (GA).

Table 2. Properties of Copper Oxide $(\mathrm{CuO})$ and amino acid composition for Gum Arabic (GA) [16, 17]

\begin{tabular}{ccc}
\hline & Appearance & Black colour \\
& Solubility in water & Soluble \\
& Odour & Odourless \\
CopperOxide (CuO) & Boiling point & $2000\left[{ }^{\circ} \mathrm{C}\right]$ \\
& Melting point & $1201\left[{ }^{\circ} \mathrm{C}\right]$ \\
& Molecular Mass & $79.55[\mathrm{~g} / \mathrm{mol}]$ \\
& Thermal Conductivity & $76[\mathrm{~W} / \mathrm{m} . \mathrm{K}]$ \\
& Density & $6.31\left[\mathrm{~g} / \mathrm{cm}^{3}\right]$ \\
\hline & Aspartic acid & 50 \\
Glutamic acid & 29 \\
Gum Arabic (GA) & Histidine & 44 \\
& Hydroxyproline & 328 \\
& Leucine & 67 \\
& Methionine & 1 \\
& Phenylalanine & 22 \\
& Proline & 88 \\
& Valine & 36 \\
\hline
\end{tabular}

\subsection{Measuring devices}

Several parameters have been measured through the experimental test. They have been carried from the morning at 7:00 AM until the sunset at 6:30 PM during summer season and from the morning at 7:00 AM until the sunset at 5:30 PM during the winter season. The water temperatures in basin $\left(T_{w, b}\right)$, inner glass surface temperatures $\left(T_{g, i n}\right)$, outer glass surface temperatures $\left(\mathrm{T}_{\mathrm{g}, \text { out }}\right)$, the ambient temperature $\left(\mathrm{T}_{\mathrm{amb}}\right)$, working fluid temperatures inlet and outlet of the PTC $\left(T_{p}\right.$,in and $\left.T_{p, o u t}\right)$, working fluid temperatures inlet to solar still $\left(T_{s, \text { in }}\right)$, fluid temperatures out solar still $\left(\mathrm{T}_{\mathrm{s}, \mathrm{out}}\right)$, temperature plate heat exchanger $\left(T_{p}\right)$ and the temperature of the receiver tube surface $\left(T_{r}\right.$,tube $)$ were all measured at the same time by using set of $\mathrm{K}$ type thermocouples. The data logger is used to collect the recorded temperatures were measured by the thermocouples as shown in Figure 5A. Solar irradiance (G) was reported by a digital solar power meter to measure the solar irradiance with a range $2000 \mathrm{~W} / \mathrm{m}^{2}$ and the variation of wind speed was measured through an anemometer (see Figure 5B and C).

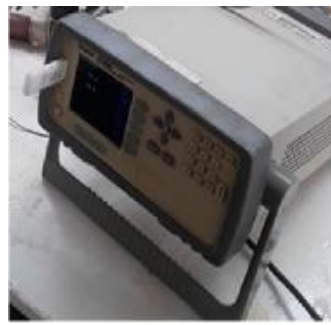

(A)

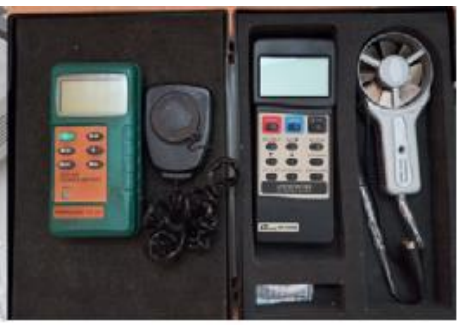

(B)
(C)
Figure 5. Measuring devices: A) Data logger, B) Digital solar power meter, and D) Anemometer air velocity 
All the experimental tests were completed at the Al-Furat Al-Awsat Technical University, Engineering Technical College Najaf $\left(32^{\circ} 1^{\prime} \mathrm{N} / 44^{\circ} 19^{\prime} \mathrm{E}\right)$ for the different months of summer, winter, spring and autumn 2020 and 2021. The various factors that have been examined in this experimental test were using: (a) parabolic trough collector, (b) nanofluid as working fluid, and (c) heat exchanger inside the traditional solar still. Every factor has many experimental tested days. The suggested solar still has the same standard still dimensions except it has made of cork and has a heat exchanger inside the water basin still.

\section{UNCERTAINTY ANALYSIS OF THE DEVICES}

The temperature changes for different parts of the proposed system were reported by using calibrated thermocouples ktype, they have a range, uncertainty and accuracy of -50 to $280^{\circ} \mathrm{C} \pm 0.152^{\circ} \mathrm{C}$ and $\pm 1^{\circ} \mathrm{C}$ respectively. While the wind speed variance was recorded by employing a digital anemometer Lutron Taiwan, Model: YK-80 AM With Metal Van, with having a range, uncertainty and accuracy of $0.8-40 \mathrm{~m} / \mathrm{sec}$, $\pm 0.17 \mathrm{~m} / \mathrm{sec}$ and $\pm 0.5 \mathrm{~m} / \mathrm{sec}$, respectively. While the solar irradiance has been measured by a solar meter with a scale, uncertainty and accuracy of $0-2000 \mathrm{~W} / \mathrm{m}^{2}, 0.1 \mathrm{~W} / \mathrm{m}^{2}$ and \pm 10 $\mathrm{W} / \mathrm{m}^{2}$, respectively. The accuracy of an estimated value reported from the uncertainty of any recorded test parameter was analyzed to verify the measured data. The uncertainty analysis of the proposed system can be calculated by the below equation and depending on the error of the measured data [18].

$$
U_{T}=\sqrt{\left(\frac{\partial T}{\partial X_{1}} \times U_{1}\right)^{2}+\left(\frac{\partial T}{\partial X_{2}} \times U_{2}\right)^{2}+\cdots \cdots+\left(\frac{\partial T}{\partial X_{n}} \times U_{n}\right)^{2}}
$$

where, $U_{T}$ is the uncertainty in the result and $U_{1}, U_{2} \ldots \ldots U_{n}$ are the uncertainties in the independent variables (such as; temperature, solar irradiance, wind speed flowrate ...et.al.).

\section{THERMODYNAMICS ANALYSIS OF SINGLE SOLAR STILL}

Through the working time, the suggested solar still produces a quantity of freshwater equivalent to $P_{h}$. The $T_{p}, T_{g}$, $\mathrm{T}_{\mathrm{w}, \mathrm{b}}$ and $\mathrm{T}_{\mathrm{amb}}$ are the medium temperatures for absorber plate, glass cover, basin water and ambient, respectively. The single solar still receive solar irradiance $G$. The working of the suggested solar still is directed by the heat energy balance equations. The thermal energy balance equation of the glass cover is equal to the thermal energy absorbed by the solar still glass cover through solar irradiance minus the loss of the thermal energy.

$$
q_{g}=\alpha_{g} G-q_{L, g}
$$

where:

$$
\begin{gathered}
q_{L, g}=q_{c o n, g}+q_{\text {rad }, g} \\
q_{c o n, g}=h_{c o n, g}\left(T_{g}-T_{0}\right) \\
q_{\text {rad }, g}=\varepsilon_{g} \sigma\left[T_{g}-\left(T_{0}-11\right)^{4}\right]
\end{gathered}
$$

where, $q_{L, g}$ is the amount of heat losses to the surrounding through the glass cover $\left[\mathrm{W} / \mathrm{m}^{2}\right], q_{c o n, g}$ and $q_{\text {rad,g }}$ are the amount of heat losses to the surrounding by convection and radiation, respectively $\left[\mathrm{W} / \mathrm{m}^{2}\right]$.

The main amount of heat emission depends on convection by air flowing and on the heat radiation to the sky. The heat transfer by radiation to sky depends on the temperature of sky, which is suggested equal to $11^{\circ} \mathrm{C}$, the $\sigma$ and $\varepsilon_{g}$ are the constant of the Stefan Boltzman $5.67 \times 10^{8} \mathrm{w} / \mathrm{m}^{2} \mathrm{~K}^{4}$.and glass emissivity, respectively.

Where $h_{c o n, g}$ is the convection heat transfer coefficient to the ambient through the glass cover $\left[\mathrm{W} / \mathrm{m}^{2} \mathrm{~K}\right][11]$.

$$
h_{\text {con, },}=5.7+3.8 \mathrm{~V}
$$

where, $V$ is the wind speed $[\mathrm{m} / \mathrm{s}]$

While the thermal energy equation of the water inside the still is [19]:

$$
q_{i b w}=(\tau \alpha)_{w} G+q_{f}-q_{L, w}
$$

where, $(\tau \alpha)_{w}$ is the thermal transmissivity absorptivity of water $(0.816)$.

The thermal energy losses from the water basin $q_{\text {Losses }, w}$ can be obtained:

$$
q_{L, w}=q_{e v a, w}+q_{r a d, w}+q_{c o n, w}+q_{L, b}
$$

The rate of heat transfer by evaporation from the surface of saltwater $q_{\text {eva,w }}$ which is an effect on the amount of distilled freshwater $P_{h}$.

$$
q_{\text {eva }, w}=\frac{P_{h} * 10^{-6} * \rho_{w} * L_{h, w}}{3600}
$$

where, $L_{h, w}$ is the amount of latent heat at the temperature of a glass cover (equal to $2350 \mathrm{~kJ} / \mathrm{kg}$ ).

By the below equation have been calculated the thermal efficiency:

$$
\eta_{\text {system }}=\frac{P_{d} * 10^{-6} * \rho_{w} * L_{h, w}}{3600 * G_{d}}
$$

where, $G_{d}$ and $P_{d}$ are the solar irradiance and freshwater product during the daily, respectively.

The heat transfer by radiation between the saltwater and the glass cover can be calculated by:

$$
q_{\text {rad,w }}=\sigma * F_{(w-g)} *\left(\varepsilon_{w} * T_{w, b}^{4}-\varepsilon_{g} * T_{g, i n}^{4}\right)
$$

where, $\varepsilon_{g}$ and $\varepsilon_{w}$ are the absorptivity of the glass cover (0.89) and saltwater (0.96), respectively. The $F_{(w-g)}$ is the radiation shape factor from saltwater to the glass cover (0.9).

The rate of heat transfer by convection from the saltwater to the glass cover is calculated by:

$$
q_{c o n, w}=h_{c o n, w}\left(T_{w, b}-T_{g, i n}\right)
$$

where, $h_{c o n, w}$ is the convective heat transfer coefficient can be calculated by following equation. 


$$
\begin{aligned}
h_{\text {con }, w}=8.84 \times 10^{-4} & \times\left(T_{w, b}-T_{g, \text { in }}\right) \\
& \times\left\{\left(T_{w, b}-T_{g, \text { in }}\right)\right. \\
+ & {\left.\left[\frac{P_{w}-P_{g}}{2.65 \times\left(P_{a t m}-P_{w}\right)}\right] \times T_{w, b}\right\}^{1 / 3} }
\end{aligned}
$$

where, $P_{w}, P_{g}$ and $P_{a t m}$ are water vapor pressure, water vapor pressure and atmospheric pressure, respectively.

While the heat transfer from the working fluid $q_{f}$ to the salt water is:

$$
q_{f}=\dot{m}_{w} C_{P_{w}}\left(T_{p, \text { in }}-T_{p, o u t}\right)
$$

From Eq. (14) can calculate the outlet temperature of the working fluid:

$$
T_{p, \text { out }}=T_{p, \text { in }}+\frac{q_{f}}{m_{w} C_{P w}}
$$

The heat losses from the water basin base to the outside is:

$$
q_{L, b}=h_{L, b}\left(T_{w, b}-T_{a m b}\right)
$$

where, $h_{l o s, b}$ is the coefficient of heat transfer by convection from the basin base to the ambient, which is affected by the thickness and the thermal conductivity of the insulation:

$$
h_{L, b}=\frac{K_{\text {in }}}{X_{\text {in }}}
$$

where, $X_{\text {in }}$ and $K_{\text {in }}$ are the insulation thickness $(0.05 \mathrm{~m})$ and thermal conductivity $\left(0.03 \mathrm{~W} /{ }^{\circ} \mathrm{C}\right)$, respectively.

\section{EXPERIMENTAL RESULTS AND DISCUSSION}

The experimental data results were reported and the single slope solar still productivity and performance were considered through the summer season months of May, June, July, and August 20121. Solar irradiance impacts the performance of the PTC since its intensity varies throughout the day, affecting the quantity absorbed by the receiver tube. Certain days have been chosen based on days of clear sky weather.

Figure 6 highlights the relationship between solar irradiance and ambient temperature over two different days. The maximum radiation was recorded at $12: 15 \mathrm{pm}$ where the highest solar radiation was recorded $1022 \mathrm{~W} / \mathrm{m}^{2}$ see Figure $6 \mathrm{~A}$. The surrounding temperature begins to rise and decreases after $3: 30$, the highest temperature obtained is $35.8^{\circ} \mathrm{C}$ on the evening of March as shown in Figure 6B. On another day, the radiation was reported at $12: 00 \mathrm{pm} 1160 \mathrm{~W} / \mathrm{m}^{2}$ where the highest temperature was obtained at $39.5^{\circ} \mathrm{C}$ in the afternoon and then began to decrease after $4 \mathrm{pm}$.

Figure 7 shows the variation of working fluid temperatures inlet the PTC, fluid temperatures outlet the PTC and temperature of receiver tube surface during the two experimental days May and June. As shown in Figure 7B, the maximum outlet working fluid (nanofluid copper oxide) temperature of the parabolic solar collector was greater than that of the conventional solar still by $\sim 12^{\circ} \mathrm{C}$.
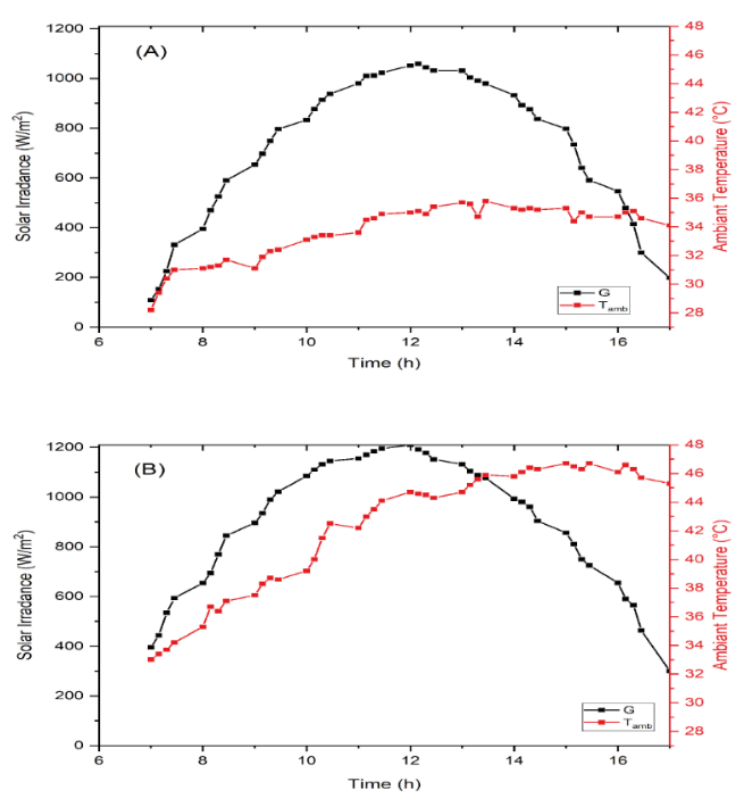

Figure 6. Hourly solar irradiance and ambient temperatures variations for single slope solar still combined with parabolic trough collectors in, (a) 6 May 2021 and 24 June 2021
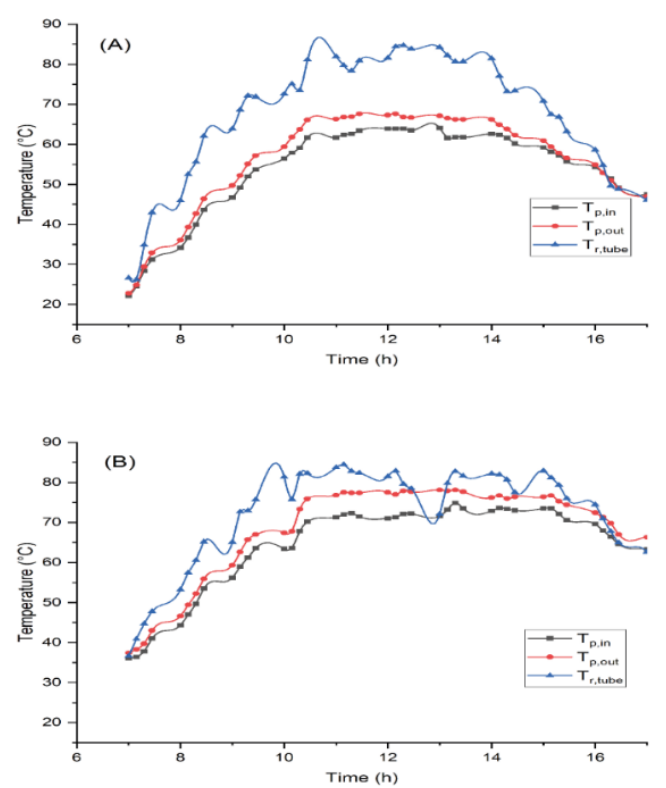

Figure 7. Hourly temperatures variations for the parabolic trough collectors, (A) water as working fluid on 6 May 2021,

(B) nanofluid is copper oxide $(\mathrm{CuO})$ on 24 June 2021

The influence of connect the PTC and heat exchanger plate on temperatures of different solar still parts (glass surface, water and heat exchanger plate) for two type working fluids under the Najaf city of Iraq weather condition is shown in Figure 8. The results show that the maximum water temperature and temperature of plate were in the in the when using the nano fluid as working fluid compared with conventional still (water). The maximum temperature of inside and outside glass, plate and water surface are found to be 72 , 68,82 and $77.7^{\circ} \mathrm{C}$ respectively. 

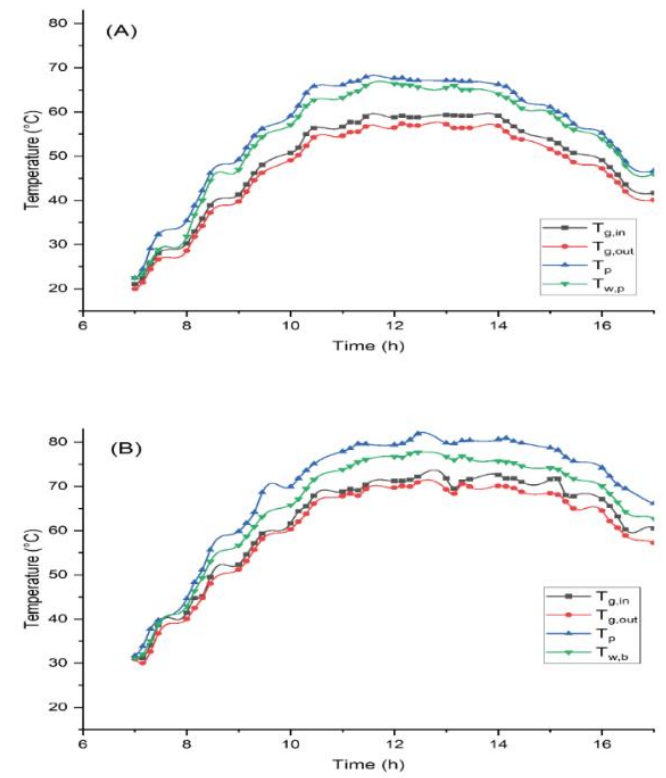

Figure 8. Hourly temperatures variations for the single slop solar still, (A) water as working fluid on 6 May 2021, (B)

nanofluid is copper oxide $(\mathrm{CuO})$ on 24 June 2021
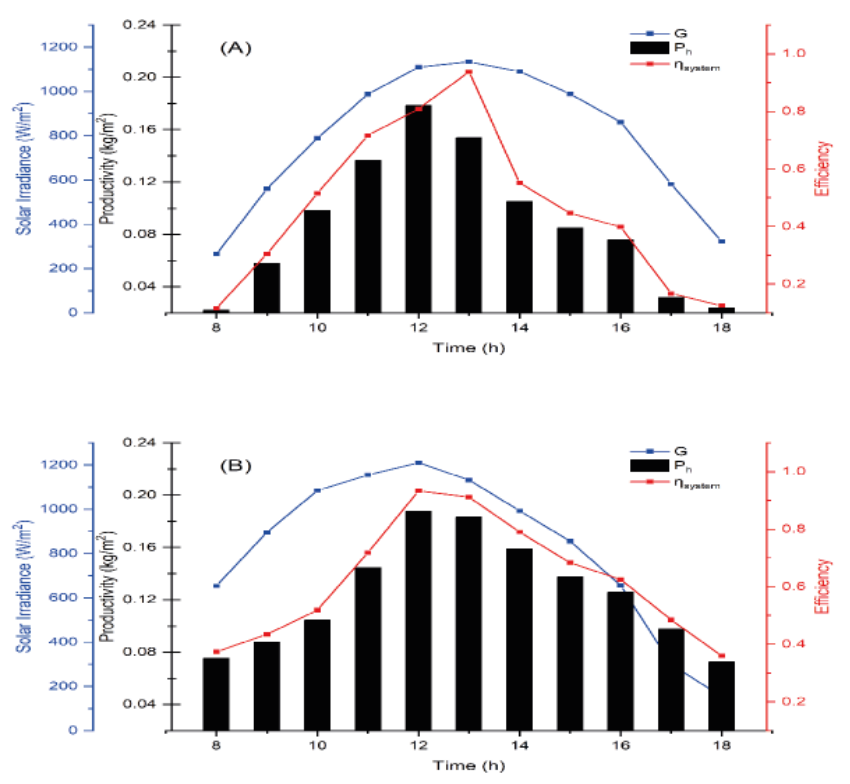

Figure 9. Comparison of fresh water productivity for different working fluid types; (A) water as working fluid on 6 May 2021, (B) nanofluid is copper oxide $(\mathrm{CuO})$ on 24 June 2021

The freshwater productivity from the PTC with single slope solar still for two various working fluids; water and nanofluid $(\mathrm{CuO})$, on 6 May and 24 June respectively, have been investigated and compared in Figure 9. It represents the variation of hourly thermal efficiency for the water and nanofluid $(\mathrm{CuO})$ solar still.

Figure 9A shows the relationship between solar radiation, yield of distilled water and thermal efficiency when water is used as a fluid flowing inside the pipes. It was found that at the highest solar radiation of at $12: 00 \mathrm{pm}$, the highest productivity of $0.179 \mathrm{~kg} / \mathrm{hr}$ was obtained, which leads to obtaining the highest thermal efficiency of 0.93 at 12:00.
Figure 9B shows the relationship between solar radiation and the productivity of distilled water and the thermal efficiency when using $\mathrm{CuO}$ nanoparticles with water. The results show at the highest solar radiation, the highest productivity is obtained at 12:00 pm. The productivity improvement rate is $42.2 \%$. Which leads to an improvement in thermal efficiency of $34.39 \%$.

Normally, the thermal efficiency and productivity shoot down at $18 \mathrm{~h}$ because the value of solar intensity is very low (see Figure 9A). While they increased at the end of the day (see Figure 9B) due to the nanofluids kept some of the heat and release it at sunset.

\section{CONCLUSION}

Solar productivity is still influenced by a number of factors and varies depending on the weather conditions of Al-Najaf City-Iraq ( $\left.32^{\circ} 1^{\prime} \mathrm{N} / 44^{\circ} 19^{\prime} \mathrm{E}\right)$. It also relies heavily on the evaporation and condensation processes that occurs inside the single solar still.

1- It was concluded that whenever the temperature of the fluid outside the receiving tube increases as a result of the solar radiation falling on the PTC and reflected on the tube. The temperature of the plate inside the solar still increases, so the temperature of the water inside the solar still increases, so the evaporation process inside the solar still increases, which increases the productivity of distilled water.

2- The productivity of distilled water and the thermal efficiency of the conventional solar distiller increases when combined with PTC using copper oxide nanofluid $(\mathrm{CuO})$ as a fluid flowing inside the tubes. (PTC receiver tube and heat exchanger tube inside the single solar still basin). The improvement in productivity compared to water use is $42.2 \%$. The thermal efficiency also increases, reaching $62.136 \%$ during the day

\section{REFERENCES}

[1] Madiouli, J., Lashin, A., Shigidi, I., Badruddin, I.A., Kessentini, A. (2020) Experimental study and evaluation of single slope solar still combined with flat plate collector, parabolic trough and packed bed. Sol Energy, 196:

358-366. https://doi.org/10.1016/j.solener.2019.12.027

[2] Fathy, M., Hassan, H., Salem Ahmed, M. (2018). Experimental study on the effect of coupling parabolic trough collector with double slope solar still on its performance. Sol Energy, 163: 54-61. https://doi.org/10.1016/j.solener.2018.01.043

[3] Hassan, H., Ahmed, M.S., Fathy, M. (2019). Experimental work on the effect of saline water medium on the performance of solar still with tracked parabolic trough collector (TPTC). Renew Energy, 135: 136-147. https://doi.org/10.1016/j.renene.2018.11.112

[4] Al-Shamkhee, D.M.H., Al-Zaini, E.O.A., Abed, Q.A. (2018). Experimental investigation of parabolic trough solar collector (PTC) performance for water desalination. TE-RE-RD 2018 7th Int. Conf. Therm. Equipment, Renew. Energy Rural Dev., pp. 21-26.

[5] Riffat, S., Mayere, A. (2013). Performance evaluation of 
v-trough solar concentrator for water desalination applications. Appl Therm Eng., 50(1): 234-244. https://doi.org/10.1016/j.applthermaleng.2012.05.028

[6] Hassan, H., Ahmed, M.S., Fathy, M., Yousef, M.S. (2020). Impact of salty water medium and condenser on the performance of single acting solar still incorporated with parabolic trough collector. Desalination, 480: 1-15. https://doi.org/10.1016/j.desal.2020.114324

[7] Morad, M.M., El-Maghawry, H.A.M., Wasfy, K.I. (2015). Improving the double slope solar still performance by using flat-plate solar collector and cooling glass cover. Desalination, 373: 1-9. https://doi.org/10.1016/j.desal.2015.06.017

[8] Harris Samuel, D.G., Nagarajan, P.K., Sathyamurthy, R., El-Agouz, S.A., Kannan, E. (2016). Improving the yield of fresh water in conventional solar still using low cost energy storage material. Energy Convers Manag., 112: $125-134$.

https://doi.org/10.1016/j.enconman.2015.12.074

[9] Olia, H., Torabi, M., Bahiraei, M., Ahmadi, M.H., Goodarzi, M., Safaei, M.R. (2019). Application of nanofluids in thermal performance enhancement of parabolic trough solar collector: State-of-the-art. Appl Sci., 9(3): 1-23. https://doi.org/10.3390/app9030463

[10] Fadhel, H., Abed, Q.A., Hachim, D.M. (2021). Numerical simulation of receiver tube for parabolic trough collector with single solar still. Turkish Journal of Physiotherapy and Rehabilitation, 32: 16861-16872.

[11] Duffie, J.A., Beckman, W.A., Prasad, S.B., et al. (2013). Solar Engineering of Thermal Processes, 4th Edition John A. Duffie, William A. Beckman.

[12] Wang, F.Q., Cheng, Z.M., Tan, J.Y., Yuan, Y., Yong, S., Liu, L.H. (2017). Progress in concentrated solar power technology with parabolic trough collector system: A comprehensive review. Renew Sustain Energy Rev., 79: 1314-1328. https://doi.org/10.1016/j.rser.2017.05.174

[13] Goudarzi, K., Nejati, F., Shojaeizadeh, E., Asadi Yousefabad, S.K. (2015). Experimental study on the effect of $\mathrm{pH}$ variation of nanofluids on the thermal efficiency of a solar collector with helical tube. Exp Therm Fluid Sci., 60: 20-27. https://doi.org/10.1016/j.expthermflusci.2014.07.015

[14] Borode, A.O., Ahmed, N.A., Olubambi, P.A. (2019). Surfactant-aided dispersion of carbon nanomaterials in aqueous solution. Phys Fluids, 31(7). https://doi.org/10.1063/1.5105380

[15] Anderson, D.M.W., Wang, W.P. (1990). The characterization of Acacia paolii gum and four commercial Acacia gums from Kenya. Top Catal., 3(6): 475-484. $005 \mathrm{X}(09) 80225-7$

[16] Forsyth, J.B., Hull, S. (1991). The effect of hydrostatic pressure on the ambient temperature structure of $\mathrm{CuO}$. J Phys Condens Matter., 3(28): 5257-5261. https://doi.org/10.1088/0953-8984/3/28/001

[17] Anderson, D.M.W., Howlett, J.F., McNab, C.G.A. (1985). The amino acid composition of the proteinaceous component of gum Arabic (Acacia Senegal (1.) willd.).

Food Addit Contam., 2(3):

159-164. https://doi.org/10.1080/02652038509373539

[18] Omara, Z.M., Abdullah, A.S., Dakrory, T. (2017). Improving the productivity of solar still by using water fan and wind turbine. Sol Energy, 147: 181-188. https://doi.org/10.1016/j.solener.2017.03.041

[19] Abdel-Rehim, Z.S., Lasheen, A. (2007). Experimental and theoretical study of a solar desalination system located in Cairo, Egypt. Desalination, 217(1-3): 52-64. https://doi.org/10.1016/j.desal.2007.01.012

\section{NOMENCLATURE}

$u$

V

W

$Q_{b}$

$Q_{\text {out }}$

$G$

C.R.

$T_{\text {tube }}$

$T_{a m b}$

$V_{\text {out }}$

$h_{\text {out }}$

$R_{w}$ and $Q_{e w}$

$Q_{w c}$ and $Q_{w r}$

$h_{e w}$, and $h_{c w b}$

$T_{w b}$ and $T_{g i}$

$R_{g}$ and $Q_{\text {cdha }}$

$Q_{c h a}$ and $Q_{r w}$

$Q_{c c}$ and $Q_{r g s}$

$T_{g o}$ and $T_{s k y}$

$n$

$P_{n p}$

$V_{o, p d}$

$P_{p c}$

$\rho$

$P$
Flow velocity in $\mathrm{x}$ direction

Flow velocity in y direction

[m/s]

$[\mathrm{m} / \mathrm{s}]$

Flow velocity in z direction $\quad[\mathrm{m} / \mathrm{s}]$

The rate of heat transfer to the $\left[\mathrm{W} / \mathrm{m}^{2}\right]$ receiver tube

The rate of heat transfer to the $\left[\mathrm{W} / \mathrm{m}^{2}\right]$ ambient

The solar irradiation

$\left[\mathrm{W} / \mathrm{m}^{2}\right]$

Concentration ratio

[-]

Temperatures of receiver tube

$\left[{ }^{\circ} \mathrm{C}\right]$

Temperatures of ambient

$\left[{ }^{\circ} \mathrm{C}\right]$

Wind speed

$[\mathrm{m} / \mathrm{s}]$

Convective heat transfer $\left[\mathrm{W} / \mathrm{m}^{2} .{ }^{\circ} \mathrm{C}\right]$ coefficient

Rate of heat absorbed and $\left[\mathrm{W} / \mathrm{m}^{2}\right]$ evaporated from water

Rate of heat transfer from water $\left[\mathrm{W} / \mathrm{m}^{2}\right]$ surface by convection and radiation

Evaporative, convective $\left(\mathrm{W} / \mathrm{m}^{2} .{ }^{\circ} \mathrm{C}\right]$ coefficients from the water surface

Temperatures of water surface $\left[{ }^{\circ} \mathrm{C}\right]$ and inner glass

Rate of heat absorbed and $\left[\mathrm{W} / \mathrm{m}^{2}\right]$ condensate by glass

Rate of heat transfer from inner $\left[\mathrm{W} / \mathrm{m}^{2}\right]$ glass surface by convection and radiation

Rate of heat transfer from outer $\left[\mathrm{W} / \mathrm{m}^{2}\right]$ glass surface by convection and radiation

Temperatures of outer glass $\left[{ }^{\circ} \mathrm{C}\right]$ surface and sky

Normal component of flow field [-]

Static pressure of pump as

[Pa]

Water flow rate

$\left[\mathrm{m}^{3} / \mathrm{s}\right]$

Pressure difference between $[\mathrm{Pa}]$ inlet and outlet of pump.

The density of steam

$\left[\mathrm{kg} / \mathrm{m}^{3}\right]$

The pressure of water flow 